\title{
Effect of alginite in the form of ALGEX 6 preparation on the biomass formation and antioxidant activity of some medicinal plants
}

\author{
Vladimíra Horčinová Sedláčková1*, Jana Šimková1, Erika Mňahončáková2, Michaela Hrúzová \\ Peter Kovár ${ }^{3}$, Luboš Vozár ${ }^{3}$, Peter Hric ${ }^{3}$ \\ ${ }^{1}$ Slovak University of Agriculture in Nitra, Faculty of Agrobiology and Food Resources, \\ Institute of Biodiversity Conservation and Biosafety, Nitra, Slovakia \\ ${ }^{2}$ Slovak University of Agriculture in Nitra, Botanical Garden, Slovakia \\ ${ }^{3}$ Slovak University of Agriculture in Nitra, Faculty of Agrobiology and Food Resources, \\ Department of Crop Production and Grassland Ecosystems, Nitra, Slovakia
}

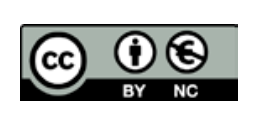

Article Details:

Received: 2021-03-12

Accepted: 2021-03-25

Available online: 2021-05-31

\begin{abstract}
The aim of the research is to determine the effect of application of the developed product (extract) called ALGEX 6 from natural mineral rock alginite in two different watering periods on the formation of root biomass and aboveground plant biomass of a selected group of medicinal plants (Melissa officinalis L., Malva verticillata L. and Ocimum $\times$ citriodorum Vis.) and determining the antioxidant activity in dried leaves and whole plants in aqueous and methyl alcohol extracts by DPPH method. The experiment was established in the Botanical Garden at the Slovak University of Agriculture in Nitra throughout 2020. ALGEX 6 was prepared by a research team at the Slovak University of Agriculture in Nitra in the form of an extract from the natural mineral rock alginite with an application of thermal and chemical treatment. In the experiment, ALGEX 6 was applied in the form of a watering in two variants with the same concentration of $3 \%$ solution in 2 decilitres of water, but various application in terms of days in the pre-harvest stage of the above-ground plant biomass of 30 individual plants from each species. There are two diametrically opposite trends of LLGEX $_{\mathrm{r}} 6$ application that are manifesting themselves in M. officinalis and M. verticillata by reducing the root and above-ground part biomass compared to the control variant. The percentage proportionality of root/ above-ground part biomass in M. officinalis decreased from 62.48/30.31 \% (control), to 45.57/18.85 \% (variant 1 ) and to $36.07 / 17.27 \%$ (variant 2), as well as in M. verticillata the root/above-ground part biomass decreased from $16.03 / 13.93 \%$ (control), to $14.97 / 9.42 \%$ (variant 1) and to $11.61 / 10.14 \%$ (variant 2). In the species Ocimum $\times$ citriodorum Vis. the opposite trend manifested. The application of ALGEX $_{\mathrm{r}} 6$ watering resulted in increasing the antioxidant activity on the tested plant parts, especially in aqueous extracts in M. officinalis (from 19.30/control to $33.61 \%$ /variant 1,2 ), also in 0 . citriodorum (from 26.56 /control to $44.16 \%$ /variant 1 ), while in methyl alcohol extracts, the antioxidant activity showed a slight increase in all tested species.
\end{abstract}

Keywords: ALGEX 6, Melissa officinalis, Malva verticillata, Ocimum × citriodorum, root, weight of above-ground part, antioxidant activity, aqueous extract, methyl alcohol extracta

\section{Introduction}

Medicinal herbs are used due to their health benefits, special aroma, taste and are considered one of the richest sources of bioactive compounds (Shanayda and Korablova, 2015; Shymanska et al., 2018; Mňahončáková et al., 2019; Ivanišová et al., 2017, 2020). The commercial development of plants as sources of antioxidants to enhance health and food

\footnotetext{
*Corresponding Author: Vladimíra Horčinová Sedláčková, Slovak University of Agriculture in Nitra, Faculty of Agrobiology and Food Resources, Institute of Biodiversity Conservation and Biosafety, Nitra, Slovakia $\triangle$ vladimira.sedlackova@uniag.sk
} 
preservation is of current interest (Rice-Evans et al., 1997). Epidemiological studies have suggested positive associations between the consumption of phenolic-rich foods or beverages and the prevention of diseases (Scalbert and Williamson, 2000; Martins et al., 2012). These effects have been attributed to antioxidant components such as plant phenolics, including flavonoids and phenylpropanoids, phenolic acids, lignan precursors, terpenes, mixed tocopherols, phospholipids, polyfunctional organic acids, other essential antioxidants such as $\beta$-carotene, vitamins $\mathrm{C}$ and E, selenium, zinc and others (Rice-Evans et al., 1996; Phippen, 1998, 2000; Svidenko et al., 2015a,b; Miraj et al., 2016). Thus, natural antioxidants have gained popularity in recent years. Antioxidants are primarily secondary metabolites contained in higher plants that eliminate free radicals that are harmful to the human body (Prugar, 2008). Antioxidants interfere with the process of oxidation by free radical reactions or reduction of hydroperoxides formed and the elimination of oxygen present. Natural antioxidants are obtained from plant material mainly as extracts, including medicinal and spicy plants such as Salvia spp. (Skybitska et al., 2015), Origanum vulgare L., Melissa officinalis L. (Rasmussen, 2011), Ocimum basilicum L., Mentha piperita L. (Svidenko et al., 2015a,b), Rosmarinus officinalis L. (Mňahončáková et al., 2019), Allium ursinum L. (Balaeva-Tichomirova and Leonovich, 2017), Malva verticillata L. (Mikhailova and Ebel, 2015), Symphytum spp. (Vergun et al., 2017) and other ones (Vergun et al., 2018, 2019, 2021; Shymanska et al., 2020).

Increasing or decreasing antioxidant activity in plants is conditioned by many factors. One of the factors is the growing environment. The amendment of organic or inorganic material to topsoil is considered a way to improve the physical properties of soil. Such materials affect the living space of soil microorganisms and thus also their activity (Dlapa et al., 2004; Fernandez et al., 2007; Ismail and Ozawa, 2007). The implementation of suitable natural materials that are non-toxic and their effect is almost in short time after application could be a chance for the future agriculture. One such material would be alginite. Alginite is a sedimentary laminated rock - an oil shale (Jámbor and Solti, 1975), which originated in basalt maar lakes. The name alginite originally belonged to petrographic constituent of coal residues consisting of algae (Solti, 1987). Dark laminae are rich in amorphous organic matter and well-preserved cells of green alga Botryococcus braunii (Ognjanova-Rumenova and Vass, 1998; Vass et al., 2003). The grey laminae are composed of clay minerals derived from weathered basaltic tuff. In addition to organic matter, the rock contains considerable amounts of macronutrients such as $\mathrm{P}, \mathrm{K}$, $\mathrm{Ca}, \mathrm{Mg}$, as well as numerous trace elements. Alginite is quite rich in nutrients, except nitrogen. Release of phosphorus, potassium and microelements (Gregor and Bublinec, 1999) could significantly contribute to supplying the demands of the microbial population (Ognjanova-Rumenova and Vass, 1998; Motyleva et al., 2014). Moreover, both the clay minerals and organic matter contained in alginite have high cationexchange capacities (in contrast to quartz sand), thus regulating cation concentration in the soil solution (Schachtschabel et al., 1984). The content of heavy metals lies below toxicity limits. A large specific surface area ranging from 300 to $650 \mathrm{~m}^{2} / \mathrm{g}$ results in a water retention capacity of approx. $110 \%$ (Russell, 1990; Vass et al., 1997; Kulich et al., 2001). Tests of alginite from the deposits in Pula and Gerce (Hungary) showed that it can be used in agriculture and forestry to improve soil quality, soil water dynamics and nutrient content, to increase organic matter content, colloid content and to protect soil against acidification, desiccation and leakage of nutrients (Vass et al., 2003). No negative side effects for the environment have been observed (Kulich et al., 2001). In agriculture, alginite is also able to improve the water and nutrients regime and increasing of soil colloids (Beláček, 2006). Organic matter of alginite is a component of some types of kerogen with a predominance of type II alongside amorphous organic matter (Vass et al., 1997).

The aim of the work was to determine the effect of application of the developed product (extract) called ALGEX $_{r} 6$ from natural mineral rock alginite in two different watering periods on the formation of root and above-ground plant biomass of three species of medicinal plants with a determination of antioxidant activity in dried leaves and dried whole plants in aqueous and methyl alcohol extracts by DPPH.

\section{Material and methodology}

\section{Environment of plants cultivation}

From each tested species Melissa officinalis L. (MO), Malva verticillate L. (MV) and Ocimum citriodorum Vis. (OC), 30 individual plants were planted in containers with a diameter of $210 \mathrm{~mm}$. Garden soil was used as a cultivation medium. The experiments were established in the Botanical Garden at the Slovak University of Agriculture in Nitra in 2020 at an altitude of $167 \mathrm{~m}$ a. s. level (Figure 1). 

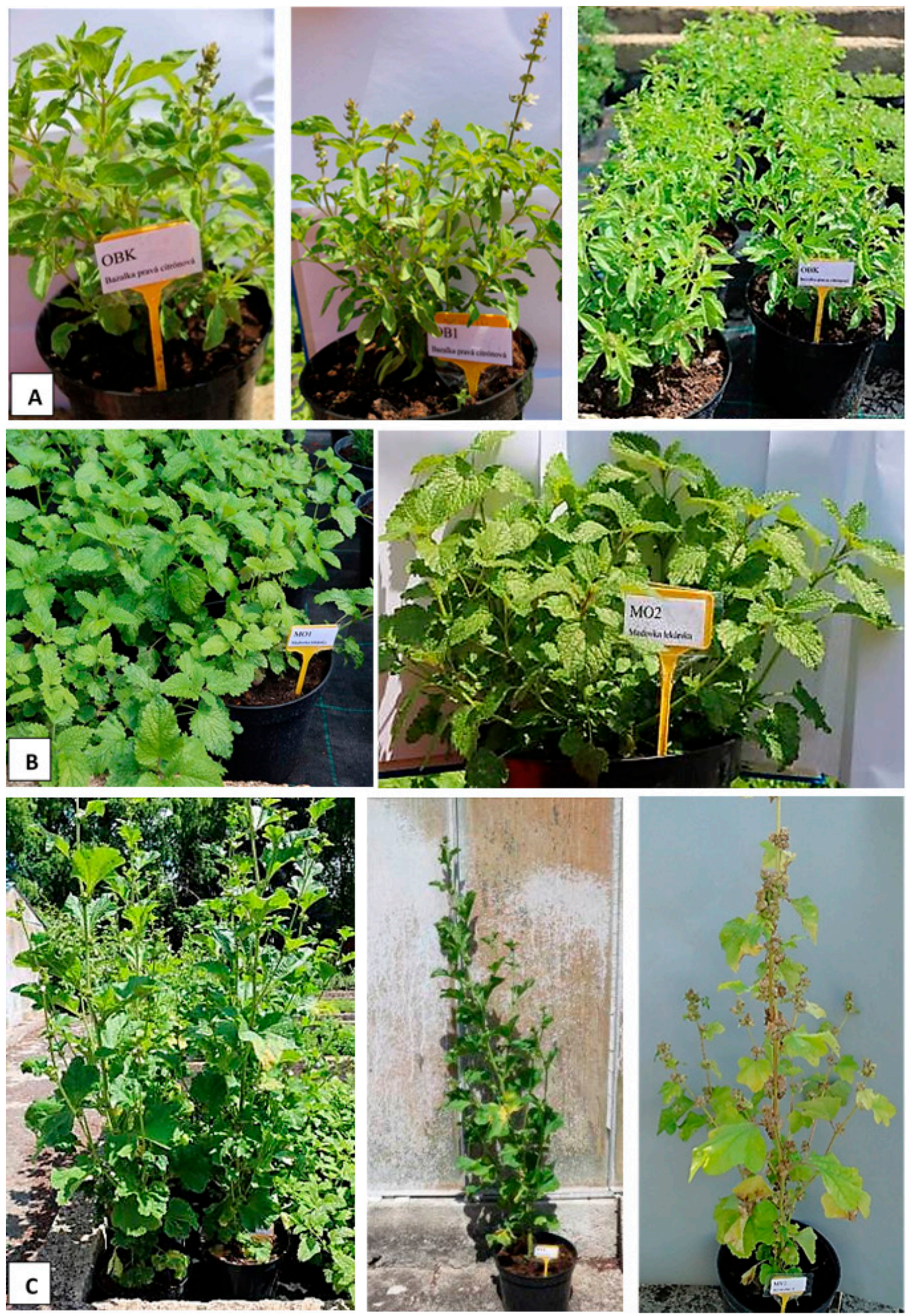

Figure 1 Demonstration of above-ground parts of medicinal plants: A - Ocimum $\times$ citriodorum Vis.; B - Melissa officinalis L.; C - Malva verticillata L. (Photo: Mňahončáková, 2020) 


\section{Application of ALGEX $\mathrm{r} 6$ preparation}

ALGEX $_{\mathrm{r}} 6$ was prepared by a research team at the Slovak University of Agriculture in Nitra in the form of an extract from a natural mineral rock with the application of thermal and chemical treatment. The product is not registered yet.

In the experiment, $\operatorname{ALGEX}_{\mathrm{r}} 6$ was applied in the form of a watering:

1. in variant 1 - only one application in the concentration of $3 \%$ solution in $200 \mathrm{~mL}$ of water applied 10 days in the pre-harvest stage of the above-ground plant biomass,

2. in variant 2 - the first application in the concentration of $3 \%$ solution in $200 \mathrm{~mL}$ of water applied 20 days in the pre-harvest stage of the above-ground plant biomass and the second application in the concentration of $3 \%$ solution in $200 \mathrm{~mL}$ of water applied 10 days in the preharvest stage of the above-ground plant biomass,

3. control variant (marked C) - without application of ALGEX $_{r} 6$ was implemented in each plant species (Table 1).

At the end of our experiment, the plants were removed from the containers. The roots of the plants were washed from the soil under running water. After drying in an unheated greenhouse, the weight of the roots and above-ground plant biomass was determined individually for each plant.

\section{Free radical scavenging activity}

The antiradical activity of dried leaves and dried above-ground plant biomass of medicinal plants were determined in methanolic (ME) and aqueous extract (AE). The samples $1 \mathrm{~g}$ in $25 \mathrm{~mL}$ water/methyl alcohol were mixed for 12 hours and antiradical activity was determined after filtration of samples. In the frame of antiradical activity (ability to eliminate the free radicals) was tested the capacity of medicinal plants to remove DPPH• radicals (2,2-diphenyl-1-picrylhydrazyl) using methods of Brand-Williams et al. (1995). Absorbance at $515 \mathrm{~nm}$ has been registered in regular time intervals until the reaction equilibrium was reached - using the GENESYS 20 Vis Spectrophotometer (Thermo Fisher Scientific Inc., USA). First was measured the DPPH• (Sigma Aldrich, USA) absorbance without antioxidant substance (control). The inhibition of DPPH• radicals was calculated in percent of free DPPH $\bullet$ radicals in the samples using the method of Von Gadow et al. (1997):

$$
\% \operatorname{Inh}=\frac{A_{0}-A_{1}}{A_{0}} \cdot 100
$$

where: $A_{0}$ is the absorbance of control in time $t=0$ min (DPPH• solution), $A_{1}$ is the absorbance in the presence of antioxidant in time $t(\mathrm{~min})$, the result is in \% of $\mathrm{DPPH} \bullet$ radical inhibition

\section{Statistical analysis}

It was evaluated the variability of the test files in each character using descriptive statistics. For the characteristics of the files, it was used the basic

Table 1 Determination of antioxidant activity in plant parts in aqueous extracts (AE) and methyl alcohol extracts (ME) in tested plant species grown in variants

\begin{tabular}{|c|c|c|c|c|}
\hline & Variants & Melissa officinalis L. (MO) & Malva verticillata L. (MV) & Ocimum $\times$ citriodorum Vis. (OC) \\
\hline \multirow{6}{*}{ 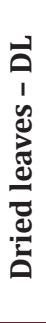 } & Control - C - AE & MOC-DLAE & MVC-DLAE & OCC-DLAE \\
\hline & Variant $1-\mathrm{AE}$ & M01-DLAE & MV1-DLAE & OC1-DLAE \\
\hline & Variant $2-\mathrm{AE}$ & MO2-DLAE & $*$ & $*$ \\
\hline & Control - C - ME & MOC-DLME & MVC-DLME & OCC-DLME \\
\hline & Variant 1 - ME & M01-DLME & MV1-DLME & OC1-DLME \\
\hline & Variant 2 - ME & MO2-DLME & $*$ & $*$ \\
\hline \multirow{6}{*}{ 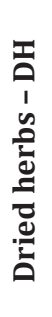 } & Control - C - AE & MOC-DHAE & MVC-DHAE & OCC-DHAE \\
\hline & Variant $1-\mathrm{AE}$ & M01-DHME & MV1-DHME & OC1-DHME \\
\hline & Variant $2-\mathrm{AE}$ & MO2-DHME & $*$ & $*$ \\
\hline & Control - C - ME & MOC-DHME & MVC-DHME & OCC-DHME \\
\hline & Variant 1 - ME & M01-DHME & MV1-DHME & OC1-DHME \\
\hline & Variant 2 - ME & MO2-DHME & $*$ & $*$ \\
\hline
\end{tabular}

Note: * - untested variants; DL - dried leaves; DH - dried herbs; AE - aqueous extract; ME - methyl alcohol extract 
descriptors of variability: average, minimum measured value, maximum measured value, the coefficient of variation (\%). Data were analyzed with ANOVA test and differences between means compared through the Fisher test $(\alpha=0.05)$. The degree of variability was determined by the coefficient of variation values. The given parameter is independent of the unit of the evaluated character. Theoretically, they can acquire different values (Stehlíková, 1998).

\section{Results and discussion}

\section{Melissa officinalis (MO)}

In our experiment with the application of an innovated preparation of alginite $\left(\operatorname{ALGEX}_{\mathrm{r}} 6\right)$ in the form of watering for selected medicinal herbs grown in containers in two different variants, we determined the following effects on the evaluated parts of plants. The average weight of the root was determined in the range from $36.70 \mathrm{~g}$ (MO2) to $62.48 \mathrm{~g}$ (MOC), the average weight of the above-ground plant biomass in the range $17.27 \mathrm{~g}$ (MO2) - 30.31 g (MOC). The values of coefficients of variation indicate a medium to a high degree of variability (15.43 \%/MOC - 34.44\%/MO2). After application of ALGEX 6 , we recorded a higher proportion of roots (67.33\% in MOC) between the control variant (MOC) and the other two variants (M01 and M02) in comparison with above-ground plant biomass (32.67\%/MOC). After application of ALGEX $_{\mathrm{r}} 6$ watering, we recorded approximately the same proportion of the weight of roots (70.73\%/M01) and above-ground plant biomass (29.27 \%/M01) compared to the control variant (Figure 2). Analysis of variance confirmed the differences between the

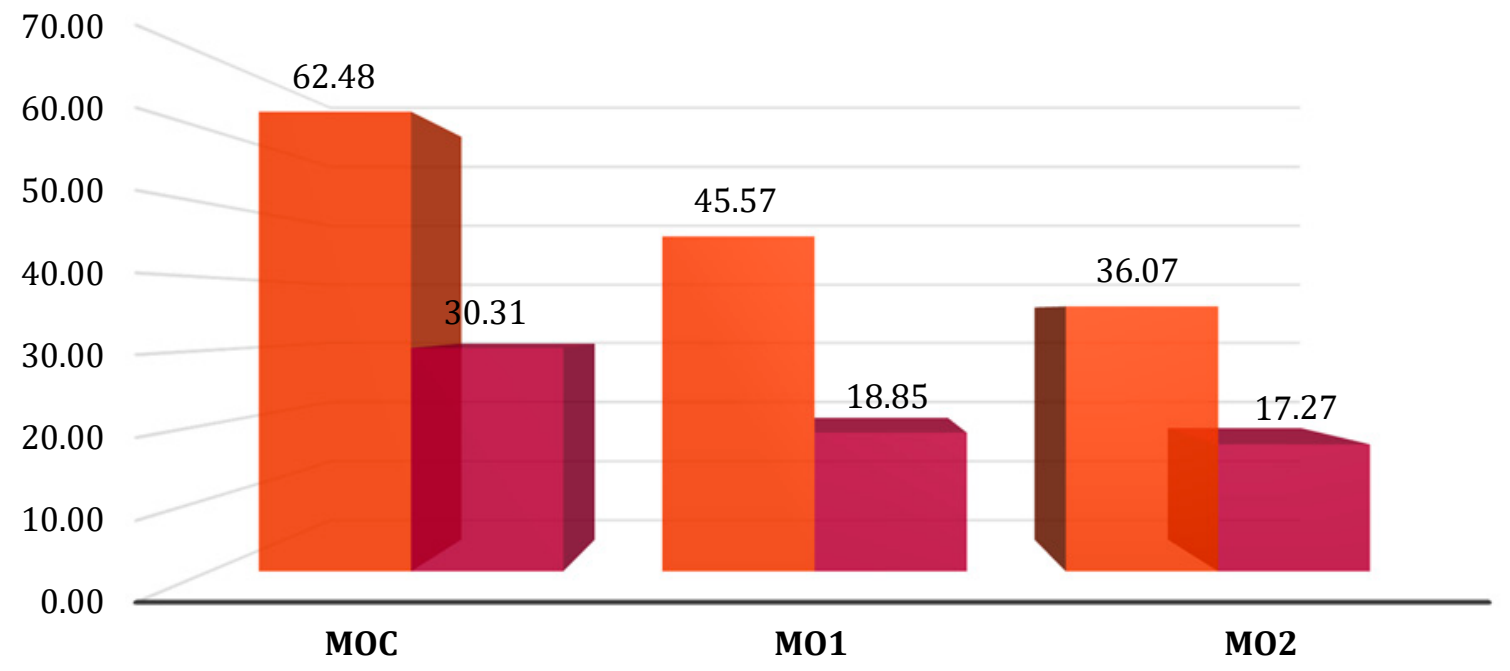

Figure 2 Comparison of the weight of Melissa officinalis L. root to the total weight of the above-ground plant biomass in the control variant and in the variants after application of ALGEX $_{\mathrm{r}}$ 6:

MOC - control; M01 - variant 1; MO2 - variant 2

Table 2 Analysis of variance to evaluate the effect of application of ALGEX 6 on the weight of roots and the weight of above-ground plant biomass of Melissa officinalis L. plants with statistical differences between the evaluated variants

\begin{tabular}{|c|c|c|c|c|c|c|c|c|c|c|c|}
\hline \multirow{2}{*}{$\begin{array}{l}\text { Source of } \\
\text { variation }\end{array}$} & SS & df & MS & $\mathbf{F}$ & p-value & F crit & \multicolumn{5}{|c|}{ Differences between variants } \\
\hline & \multicolumn{6}{|c|}{ Weight of root (g) } & Variants & $\overline{\mathbf{x}}$ & $\mathrm{V} \%$ & MO2 & M01 \\
\hline Between variants & 3579.19 & 2 & 1789.59 & 13.71 & 0.00 & 3.35 & MOC & 62.48 & 20.72 & +++ & ++ \\
\hline Within variants & 3522.66 & 27 & 130.46 & & & & M01 & 45.57 & 23.41 & - & \\
\hline Total variability & 7101.86 & 29 & & & & & MO2 & 36.07 & 29.07 & & \\
\hline \multicolumn{12}{|c|}{ Weight of above-ground plant biomass (g) } \\
\hline Between variants & 1013.50 & 2 & 506.75 & 11.63 & 0.00 & 3.35 & MOC & 30.31 & 29.22 & +++ & +++ \\
\hline Within variants & 1175.92 & 27 & 43.55 & & & & M01 & 18.85 & 21.75 & - & \\
\hline Total variability & 2189.43 & 29 & & & & & MO2 & 17.27 & 34.44 & & \\
\hline
\end{tabular}

Note: SS - sum of squares; df - degrees of freedom; MS - mean square; F - F statistic; p-value - probability ( $\alpha=0.05$ ); F crit - F-critical value; $\overline{\mathrm{x}}$ - arithmetic mean; V \% - coefficient of variation (\%); MO1 - variant 1; MO2 - variant 2 


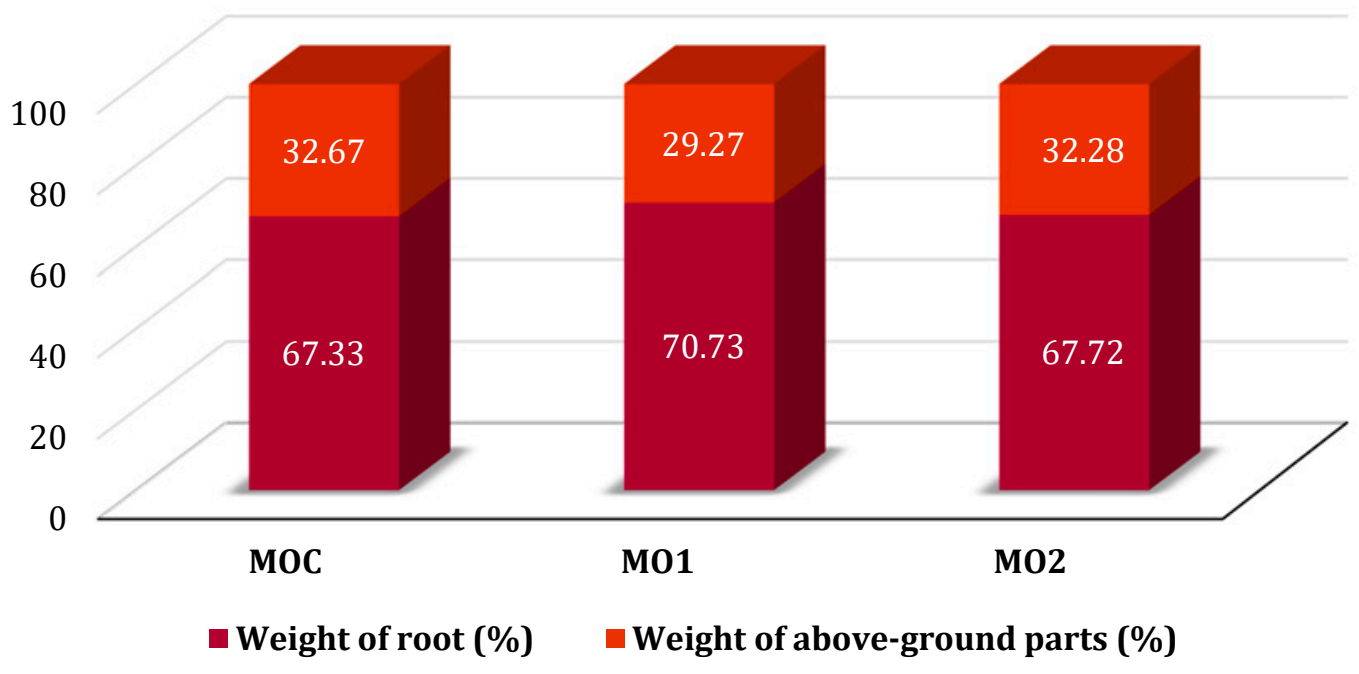

Figure 3

Comparison of the ratio of the weight of Melissa officinalis L. root (\%) and the weight of above-ground plant biomass (\%) of the total weight of the above-ground mass in the control variant and after application of ALGEX $_{\mathrm{r}}$ 6 in both variants:

MOC - control; M01 - variant 1; MO2 - variant 2

evaluated control variant and the two variants with different period ALGEX $_{\mathrm{r}} 6$ watering. We determined a statistically highly significant effect on the reduction of root weight and weight of above-ground plant biomass in both M01 and MO2 variants compared to the control variant (Table 2 and Figure 2). The results from the analysis of variance confirmed the statistically significant differences between the evaluated traits (Table 2).

In experiments, we applied ALGEX 6 two times (Variant 2 - MO2). In the aqueous extract, the smallest values of antioxidant activity were in the dried leaves of the control variant $(19.30 \%)$ and variant $1(20.56 \%)$. The highest values of antioxidant activity were achieved (MO2) dried leaves (77.74 \%) and samples of whole plants (MO2) in methyl alcohol extracts (76.27\%).

After the first application of ALGEX ${ }_{\mathrm{r}} 6$ the antioxidant activity increased especially in aqueous extracts in dried herbs (33.61\%). The effect on the increase of antioxidant activity in the evaluated traits was recorded after the second application of ALGEX 6 in both aqueous and methyl alcohol extracts (Figure 4). Results from the analysis of variance (ANOVA) of the evaluated traits (Table 3) confirm the statistically significant differences between aqueous and methyl alcohol extracts.

Table 4 and Figure 4 showed statistically significant differences between dried leaves and dried herbs in

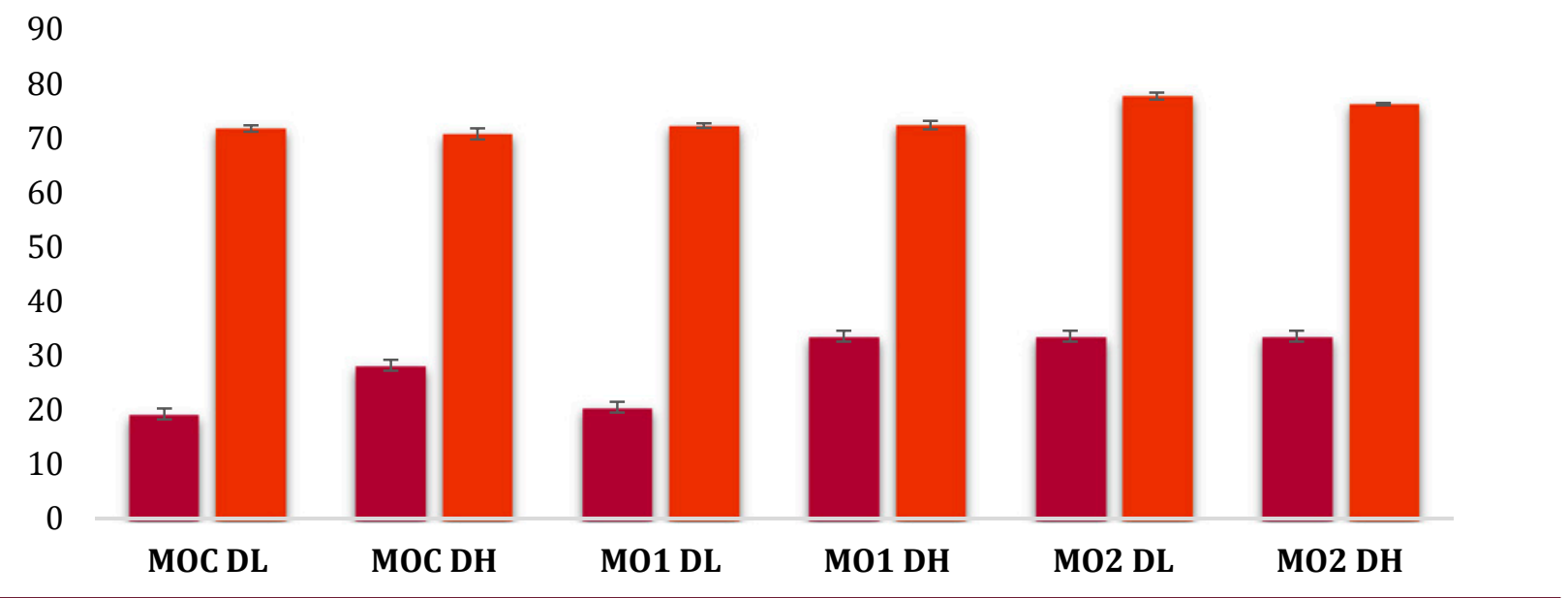

Figure 4 Comparison of antioxidant activity (\%) in dried leaves (DL) and whole plants (DH) in aqueous and methanol extracts of Melissa officinalis L. grown in control variant (MOC) and after applications of ALGEX $_{\mathrm{r}} 6$ in variants M01 and MO2 
Table 3 Analysis of variance to evaluate the antioxidant activity in aqueous and methanol extracts of Melissa officinalis L. grown in control variant (MOC) and after applications of ALGEX $_{\mathrm{r}} 6$ in variants M01 and MO2

\begin{tabular}{|l||c|c|c|c|c|}
\hline Effect & SS & df & MS & F & p-value \\
\hline \hline \multicolumn{7}{|c|}{ AA - Aqueous Extract } \\
\hline Absolute Member & 10958.30 & 1 & 10958.30 & 454.10 & 0.00 \\
\hline Variant & 508.62 & 5 & 101.72 & 4.22 & 0.02 \\
\hline Statistical Error & 289.58 & 12 & 24.13 & \\
\hline \multicolumn{7}{|c|}{ AA - Methanol Extract } \\
\hline Absolute Member & 97368.54 & 1 & 97368.54 & 74412.82 & 0.00 \\
\hline Variant & 115.91 & 5 & 23.18 & 17.72 & 0.00 \\
\hline Statistical Error & 15.70 & 12 & 1.31 & & \\
\hline
\end{tabular}

Note: AA - antioxidant activity; SS - sum of squares; df - degrees of freedom; MS - mean square; F - F statistic; p-value - probability ( $\alpha=0.05)$

Table 4 Statistical differences in antioxidant activity between dried leaves (DL) and dried whole plants (DH) of Melissa officinalis (MO) determined in aqueous (AE) and methyl alcohol extracts (ME) by Fischer test (LSD)

\begin{tabular}{|c|c|c|c|c|c|c|c|c|c|c|c|c|c|}
\hline Variants & $x$ & $\stackrel{\rho}{j}^{0}$ & 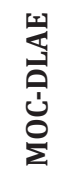 & 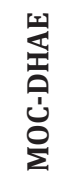 & 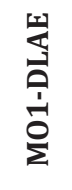 & 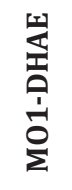 & 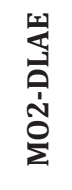 & 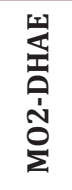 & 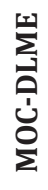 & 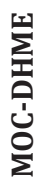 & 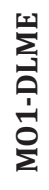 & 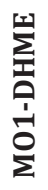 & 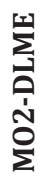 \\
\hline MOC-dried leaves aqueous extract & 19.30 & 14.80 & & & & & & & & & & & \\
\hline MOC-dried herbs aqueous extract & 28.24 & 1.10 & + & & & & & & & & & & \\
\hline M01-dried leaves aqueous extract & 20.55 & 4.26 & - & + & & & & & & & & & \\
\hline M01-dried herbs aqueous extract & 33.61 & 31.47 & + & - & + & & & & & & & & \\
\hline M02-dried leaves aqueous extract & 19.51 & 6.17 & - & + & - & + & & & & & & & \\
\hline Mo2-dried herbs aqueous extract & 26.80 & 17.66 & + & + & + & + & + & & & & & & \\
\hline MOC-dried leaves methanol extract & 71.77 & 1.41 & +++ & +++ & +++ & +++ & +++ & +++ & & & & & \\
\hline MOC-dried herbs methanol extract & 70.78 & 2.46 & +++ & +++ & +++ & +++ & +++ & +++ & - & & & & \\
\hline M01-dried leaves methanol extract & 72.30 & 1.02 & +++ & +++ & +++ & +++ & +++ & +++ & - & - & & & \\
\hline M01-dried herbs methanol extract & 72.41 & 1.87 & +++ & +++ & +++ & +++ & +++ & +++ & - & - & - & & \\
\hline M02-dried leaves methanol extract & 77.74 & 1.42 & +++ & +++ & +++ & +++ & +++ & +++ & - & - & - & - & \\
\hline M02-dried herbs methanol extract & 76.27 & 0.53 & +++ & +++ & +++ & +++ & +++ & +++ & - & - & - & - & - \\
\hline
\end{tabular}

Note: - - differences are disproven; + - differences are statistically significant; +++ - statistical significance with even smaller differences; arithmetic mean; $\mathrm{V} \%$ - coefficient of variation (\%)

methyl alcohol extracts in comparison of dried samples in aqueous extracts.

The concentration of an aqueous extract of M. officinalis capable to inhibit $50 \% \mathrm{DPPH}$ radical formation $\left(\mathrm{IC}_{50}\right.$ value) was found to be $309 \mu \mathrm{g}$ dry leaves per extract $\mathrm{mL}$, whereas for CAF $80 \mu \mathrm{g} / \mathrm{mL}$. Considering that a cup $(250 \mathrm{~mL})$ of a $2 \%$ M. officinalis infusion or decoction contains according to findings $\sim 1700-3300 \mathrm{mg}$ dry extract it can be safely said that its consumption may effectively contribute to daily radical inhibitors intake (Papoti et al., 2019). Antioxidant extract yield from raw material M. officinalis leaves was $0.4 \mathrm{~g}$ extract $/ 100 \mathrm{~g}$ plant material used rancimat method (Ribeiro et al.,
2001). M. officinalis ethanolic extracts showed a very good antioxidant activity in the DPPH test, correlated with the content in total phenols: higher in the case of $M$. officinalis leaves extract (32.76 mg GAE/g) and lower for M. officinalis stems extract (8.4 mg GAE/g) (Moacă et al., 2018).

\section{Malva verticillata (MV)}

The average weight of the root in M. verticillata was determined in the range from 11.60 (MV2) to $16.03 \mathrm{~g}$ (MVC), the average weight of the above-ground plant biomass in the range 9.42 (MV1) - $13.93 \mathrm{~g}$ (MVC). The values of the coefficients of variation indicate a medium 
Table 5 Analysis of variance to evaluate the effect of application of ALGEX $_{\mathrm{r}} 6$ on the weight of roots and the weight of above-ground plant biomass of Malva verticillata L. plants with statistical differences between the evaluated variants

\begin{tabular}{|c|c|c|c|c|c|c|c|c|c|c|c|}
\hline \multirow[t]{2}{*}{ Source of variation } & SS & df & MS & $\mathbf{F}$ & p-value & F crit & \multicolumn{5}{|c|}{ Differences between variants } \\
\hline & \multicolumn{6}{|c|}{ Weight of root (g) } & Variants & $\overline{\mathbf{x}}$ & V \% & MV2 & MV1 \\
\hline Between variants & 106.94 & 2 & 53.47 & 2.33 & 0.11 & 3.35 & MVC & 16.03 & 30.77 & ++ & - \\
\hline Within variants & 617.37 & 27 & 22.86 & & & & MV1 & 14.97 & 39.00 & - & \\
\hline Total variability & 724.32 & 29 & & & & & MV2 & 11.61 & 27.47 & & \\
\hline \multicolumn{12}{|c|}{ Weight of above-ground plant biomass (g) } \\
\hline Between variants & 117.35 & 2 & 58.67 & 4.00 & 0.02 & 3.35 & MVC & 13.93 & 35.20 & ++ & +++ \\
\hline Within variants & 395.27 & 27 & 14.63 & & & & MV1 & 9.42 & 26.73 & - & \\
\hline Total variability & 512.62 & 29 & & & & & MV2 & 10.14 & 36.25 & & \\
\hline
\end{tabular}

Note: SS - sum of squares; df - degrees of freedom; MS - mean square; F - F statistic; p-value - probability $(\alpha=0.05)$; F crit - F-critical value; $\overline{\mathrm{x}}$ arithmetic mean; V \% - coefficient of variation (\%); MV1 - variant 1; MV2 - variant 2

to a high degree of variability (14.47\%/MV2) $38.99 \% / M V 1)$. Analysis of variance determined the differences between the evaluated control variant and the two variants with different ALGEX $_{\mathrm{r}} 6$ watering. We determined a statistically highly significant effect on the reduction of root weight in the MV2 variant compared to the control variant (Table 5 and Figure 5). The application of ALGEX $_{\mathrm{r}} 6$ resulted in a statistically significant reduction in the formation of aboveground plant biomass in both variants MV1 and MV2 in comparison with the control variant (Table 6 and Figure 4). After application of ALGEX $_{r} 6$, we recorded the same proportion of roots (53\%) and aboveground plant biomass (46\%) between the control variant (MVC) and the MV2 variant. After application of ALGEX $_{\mathrm{r}} 6$ watering, we recorded an increase in the proportion of roots (61\%) compared to the proportion of above-ground plant biomass (38\%/MV1). This is documented in Figure 5. The results from the analysis of variance (Table 7) confirm the statistically significant differences between the evaluated traits.

DPPH provides a rapid, simple and sensitive method of evaluating the antioxidant activity of natural antioxidants. Application of ALGEX $_{r} 6$ in the experiment had the effect of increasing the antioxidant activity in aqueous and methyl alcohol extract. Mutual comparison of controls (MVC) and MV1 variants showed that in general we recorded higher values of antioxidant activity in methanol and aqueous extracts compared to control variants. It is evidenced that the effect of ALGEX $_{\mathrm{r}} 6$ application determines the antioxidant activity (Figure 7).

Results from the analysis of variance (Table 6) confirmed the statistically significant differences in

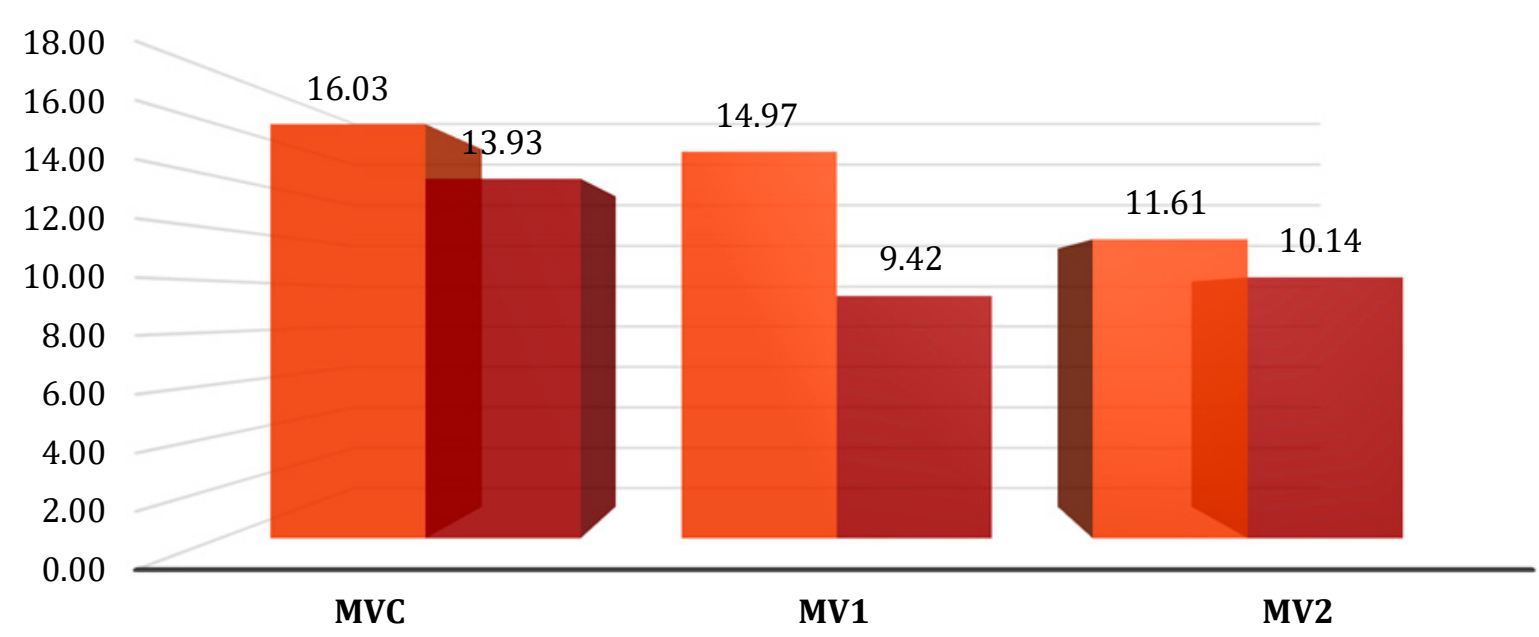

Figure 5 Comparison of the weight of Malva verticillata L. root to the total weight of the above-ground plant biomass in the control variant and in the variants after application of $\operatorname{ALGEX}_{\mathrm{r}} 6$ : MVC - control; MV1 - variant 1; MV2 - variant 2 


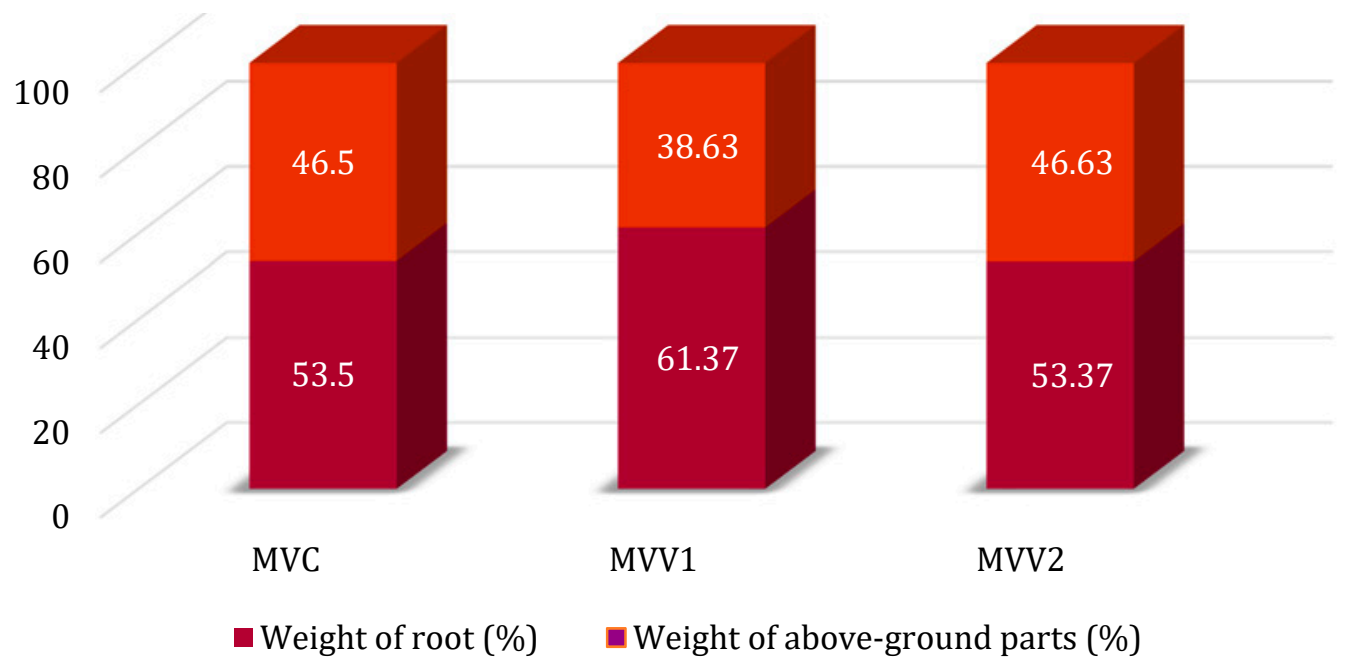

Figure 6 Comparison of the ratio of the weight of root (\%) and the weight of above-ground plant biomass (\%) of the total weight of the above-ground mass in the control variant and after application of ALGEX $_{\mathrm{r}} 6$ in both variants: MVC - control; MV1 - variant 1; MV2 - variant 2

aqueous and methyl alcohol extracts after application of ALGEX $_{r} 6$.

Table 7 showed statistically significant differences between dried leaves and dried herbs after application of alginate preparation.

Bao et al. (2018) studied the antiradical scavenging activity of fresh leaves, stems and dried seeds of $M$. verticillata by three methods. The results showed that $M$. verticillata seeds had the highest ability to scavenge DPPH free radicals (22.14 $\pm 0.59 \mathrm{mg} \mathrm{AAE} / \mathrm{g}$ extract), followed by the leaves (12.62 $\pm 0.41 \mathrm{mg} \mathrm{AAE} / \mathrm{g}$ extract) and stems (5.15 $\pm 0.19 \mathrm{mg} \mathrm{AAE} / \mathrm{g}$ extract), in that order. In addition, the seeds had higher levels of antioxidants than fatsia (19.08 $\pm 1.08 \mathrm{mg} \mathrm{AAE} / \mathrm{g}$ extract), sesame seeds (11.09 $\pm 0.57 \mathrm{mgAAE} / \mathrm{g}$ extract), bok choy (5.83 $\pm 0.44 \mathrm{mg} \mathrm{AAE} / \mathrm{g}$ extract), and broccoli (3.96 $\pm 0.21 \mathrm{mg} \mathrm{AAE} / \mathrm{g}$ extract) (Loizzo et al., 2016). The extracts of $M$. verticillata showed a strong ability to remove ABTS free radicals; the leaves had the strongest effect, at $363.83 \pm 4.22 \mathrm{mg}$ Trolox/g extract, followed by the seeds at $76.47 \pm 5.37 \mathrm{mg}$ Trolox/g extract and the stems, with the weakest effect of $46.72 \pm 5.07 \mathrm{mg}$ Trolox/g extract. The activity of each part of $M$. verticillata was stronger than those found in vegetables such as Chinese chives (30.63 $\pm 0.34 \mathrm{mg}$ Trolox/g extract) and broccoli (45.17 $\pm 2.41 \mathrm{mg}$ Trolox/g extract) (Loizzo et al., 2016). These results are different from the ability to scavenge DPPH free radicals. The leaves of $M$. verticillata exhibited the best ability to scavenge ABTS free radicals. The activity

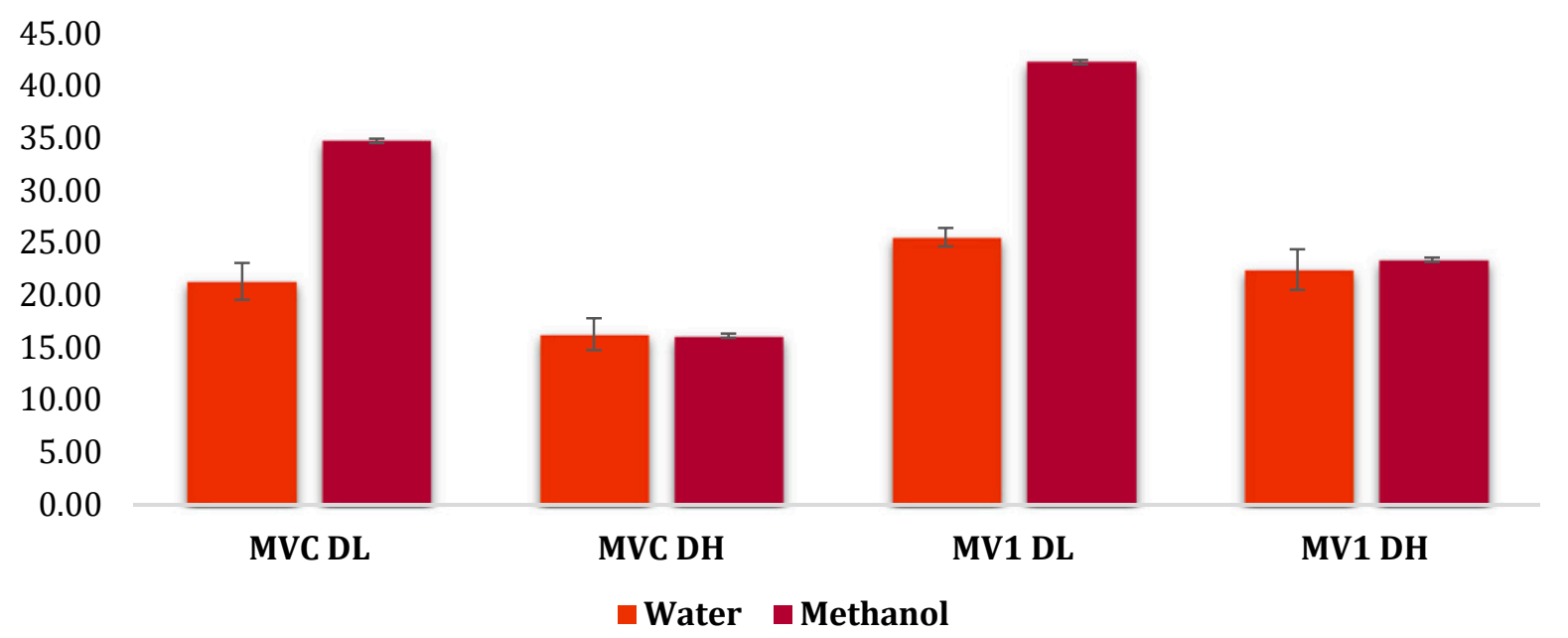

Figure 7 Comparison of antioxidant activity (\%) in dried leaves (DL) and whole plants (DH) in aqueous and methanol extracts of Malva verticillata L. grown in control variant (MVC) and after applications of ALGEX 6 in variants MV1 and MV2 
Agrobiodivers Improv Nutr Health Life Qual, 5, 2021(1): 80-94

Table 6 Analysis of variance to evaluate the antioxidant activity in aqueous and methanol extracts of Malva verticillata L. grown in control variant (MVC) and after applications of ALGEX $_{\mathrm{r}} 6$ in variants MV1 and MV2

\begin{tabular}{|l||c|c|c|c|c|}
\hline Effect & SS & df & MS & F & p-value \\
\hline \hline \multicolumn{7}{|c|}{ AA - Aqueous Extract } \\
\hline Absolute Member & 5491.17 & 1 & 5491.17 & 735.65 & 0.00 \\
\hline Variant & 133.40 & 3 & 44.47 & 5.9573 & 0.02 \\
\hline Statistical Error & 59.72 & 8 & 7.46 & \\
\hline \multicolumn{7}{|c|}{ AA - Methanol Extract } \\
\hline Absolute Member & 10178.67 & 1 & 10178.67 & 23088.43 & 0.00 \\
\hline Variant & 1217.33 & 3 & 405.78 & 920.43 & 0.00 \\
\hline Statistical Error & 3.53 & 8 & 0.44 & & \\
\hline
\end{tabular}

Note: AA - antioxidant activity; SS - sum of squares; df - degrees of freedom; MS - mean square; F - F statistic; p-value - probability ( $\alpha=0.05)$

Table 7 Statistical differences in antioxidant activity between dried leaves (DL) and dried whole plants (DH) of Malva verticillata L. (MV) determined in aqueous (AE) and methyl alcohol extracts (ME) by Fischer test (LSD)

\begin{tabular}{|c|c|c|c|c|c|c|c|c|c|c|}
\hline Variants & $x$ & $\stackrel{\circ}{\partial}$ & 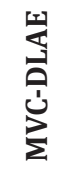 & 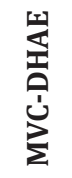 & 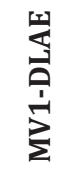 & 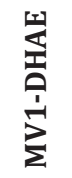 & $\begin{array}{l}\sum_{j}^{n} \\
\sum \\
\sum\end{array}$ & $\begin{array}{l}\sum^{n} \\
\vdots \\
\dot{D} \\
\sum\end{array}$ & 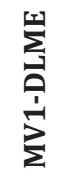 & 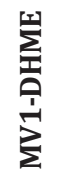 \\
\hline MVC-dried leaves aqueous extract & 21.31 & 14.25 & & & & & & & & \\
\hline MVC-dried herbs aqueous extract & 16.27 & 16.27 & + & & & & & & & \\
\hline MV1-dried leaves aqueous extract & 25.53 & 6.01 & - & + & & & & & & \\
\hline MV1-dried herbs aqueous extract & 22.42 & 14.94 & - & + & - & & & & & \\
\hline MVC-dried leaves methanol extract & 37.73 & 2.38 & +++ & +++ & +++ & +++ & & & & \\
\hline MVC-dried herbs methanol extract & 16.12 & 2.67 & + & - & + & + & +++ & & & \\
\hline MV1-dried leaves methanol extract & 42.25 & 2.06 & +++ & +++ & +++ & +++ & + & +++ & & \\
\hline MV1-dried herbs methanol extract & 23.38 & 1.51 & - & + & - & - & +++ & + & +++ & \\
\hline
\end{tabular}

Note: - - differences are disproven; + - differences are statistically significant; +++ - statistical significance with even smaller differences; arithmetic mean; V \% - coefficient of variation (\%)

of $M$. verticillata leaves was stronger than that of the seeds.

\section{Ocimum $\times$ citriodorum (OC)}

We determined the average weight of the root in the range from $3.08 \mathrm{~g}$ (OCC) to $8.20 \mathrm{~g}$ (OC1), the average weight of the above-ground plant biomass in the range $8.61 \mathrm{~g}$ (OC2) - $9.95 \mathrm{~g}$ (OCC). The values of the coefficients of variation indicate a low to the high degree of variability (7.70 \%/OCC) - $43.53 \%$ / OC2). The differences between the evaluated control variant and the two variants with different watering of ALGEX 6 indicated a statistically highly significant effect on the increased root weight in the 0C1 variant compared to the control variant and the demonstrable difference between OC1 and OC2 variant (Table 8 and Figure 8). After application of $\operatorname{ALGEX}_{\mathrm{r}}$ 6, we recorded a different proportion of roots and above-ground plant biomass between the control variant (OCC) and other variants (OC1 and OC2) where ALGEX 6 was applied 10 or 20 days in the pre-harvest stage of the aboveground plant biomass. We recorded a decrease in the proportion of above-ground plant biomass $(51.56 \%$ / OC1 and $62.60 \% / O C 2$ ) compared to the proportion of above-ground plant biomass of the control variant $(76.36 \%)$. This is documented in Figure 9. The results from the analysis of variance (Table 8) confirm the statistically significant differences only for root weights.

The basil flowers are irrelevant in terms of their usage. It is scientifically proven (Majdi et al., 2020) that $O . \times$ citriodorum is used as a natural source of bioactive substances when consumed in the form of food or extract. In general, the dried leaves and whole herbs showed higher antioxidant activity especially in the methyl alcohol extracts (Figure 10). In dried leaves and dried whole herbs, we determined significantly increased antioxidant activity in aqueous extracts after 
Table 8 Analysis of variance to evaluate the effect of application of ALGEX $_{\mathrm{r}} 6$ on the weight of roots and the weight of above-ground plant biomass of Ocimum $\times$ citriodorum Vis. plants with statistical differences between the evaluated variants.

\begin{tabular}{|c|c|c|c|c|c|c|c|c|c|c|c|}
\hline \multirow[t]{2}{*}{ Source of variation } & SS & df & MS & $\mathbf{F}$ & p-value & F crit & \multicolumn{5}{|c|}{ Differences between variants } \\
\hline & \multicolumn{6}{|c|}{ Weight of root (g) } & Variants & $\overline{\mathbf{x}}$ & V \% & oBV2 & oBV1 \\
\hline Between variants & 132.68 & 2 & 66.34 & 12.58 & 0.00 & 3.35 & OCC & 3.08 & 27.88 & - & +++ \\
\hline Within variants & 142.29 & 27 & 5.27 & & & & OC1 & 8.20 & 38.73 & ++ & \\
\hline Total variability & 274.97 & 29 & & & & & OC2 & 5.14 & 43.53 & & \\
\hline \multicolumn{12}{|c|}{ Weight of above-ground plant biomass (g) } \\
\hline Between variants & 11.12 & 2 & 5.56 & 0.68 & 0.51 & 3.35 & OCC & 9.95 & 24.27 & - & - \\
\hline Within variants & 218.50 & 27 & 8.09 & & & & OC1 & 8.73 & 35.11 & - & \\
\hline Total variability & 229.62 & 29 & & & & & OC2 & 8.61 & 34.96 & & \\
\hline
\end{tabular}

Note: SS - sum of squares; df - degrees of freedom; MS - mean square; F - F statistic; P-value - probability $(\alpha=0.05)$; F crit - F-critical value; $\overline{\mathrm{x}}$ - arithmetic mean; $\mathrm{V} \%$ - coefficient of variation (\%); OC1 - variant 1; OC2 - variant 2

alginate application, which results in increasing some biologically active substances soluble in water.

Results from the analysis of variance (Table 9) confirm the statistically significant differences between aqueous and methyl alcohol extracts.

Table 10 showed statistically significant differences between dried leaves and dried herbs in methyl alcohol extracts and aqueous extracts.

Juliani and Simon (2002) researched the antioxidant potential of dried leaves of five green and four purple basil cultivars and breeding lines by ABTS and FRAP assay showed that essential oils were a very low antioxidant activity varying from $0.05 \%$ 'Purples Ruffles' $>0.7 \%$ O. sanctum $>>2.0$ O. bassilicum to $5.9 \%$ in 'Sweet' basil (FRAP) and from $0.1 \%$ in 'Purples
Ruffles' $>0.2 \%$ O. citriodorum $>0.4 \%$ O. sanctum > $1.2 \%$ O. bassilicum to $4.1 \%$ in 'Sweet' basil (ABTS).

Hakkim et al. (2008) studied the radical scavenging ability of antioxidants of eight Ocimum species in dried form. From the percentage scavenging values the O. gratissimum extract was the most potent scavenger (81.1 $\pm 2.1 \%$ ) followed by 0 . americanum $(77.4 \pm 1.4 \%$ ) $>$ 0. minimum $(70.1 \pm 2.2 \%)>0$. citriodorum $(60.6$ $\pm 2.5 \%)>0$. kilimandscharicum $(56.2 \pm 2.1 \%)>$ O. grandiflorum $(51.3 \pm 2.3 \%)>0$. lamiifolium $(46.2 \pm 2.2 \%)>0$. selloi $(42.4 \pm 2.4 \%)$.

Kovár et al. (2021) studied the influence of alginite (powder, crushed alginite) and extracts from it (sodium solution, potassium solution) on parameters as germination dynamics, average germination, germination rate and mean germination time of Kentucky bluegrass (Poa pratensis L.). The positive

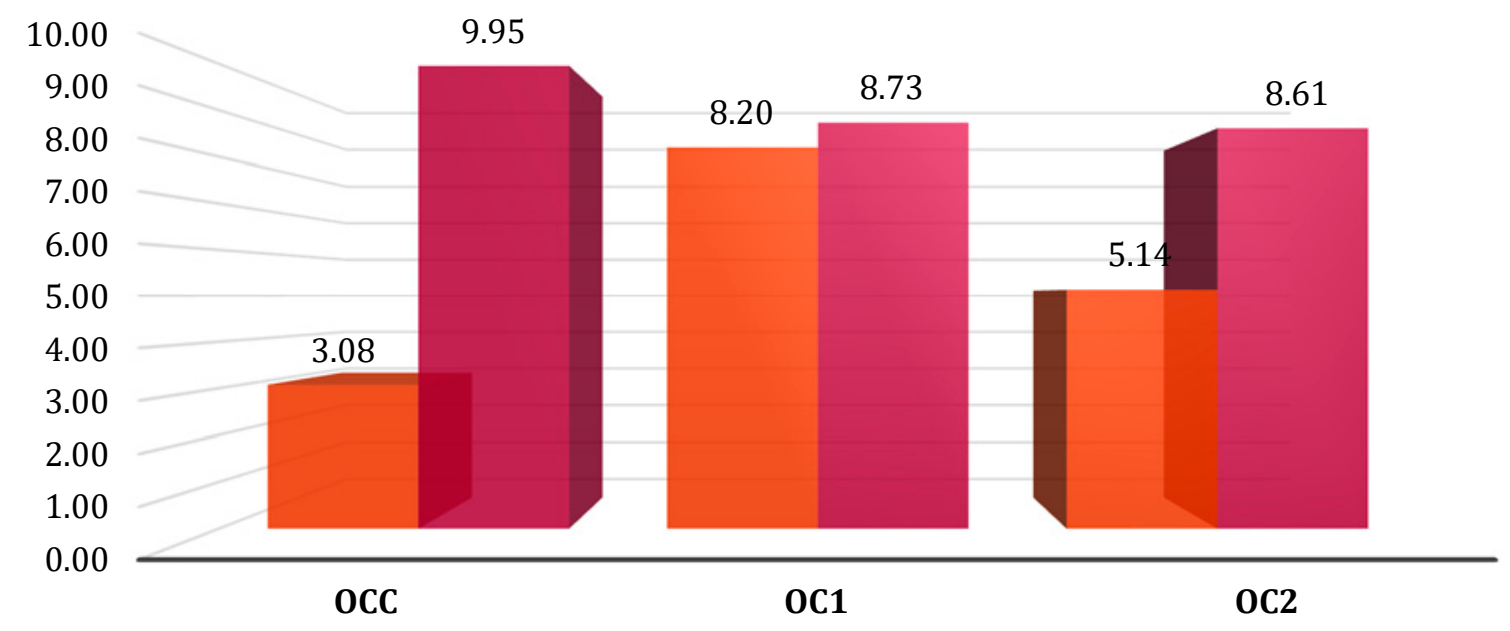

Figure 8 Comparison of the weight of Ocimum $\times$ citriodorum Vis. root to the total weight of the above-ground plant biomass in the control variant and in the variants after application of $\operatorname{ALGEX}_{\mathrm{r}} 6$ :

OCC - control; OC1 - variant 1; OC2 - variant 2 


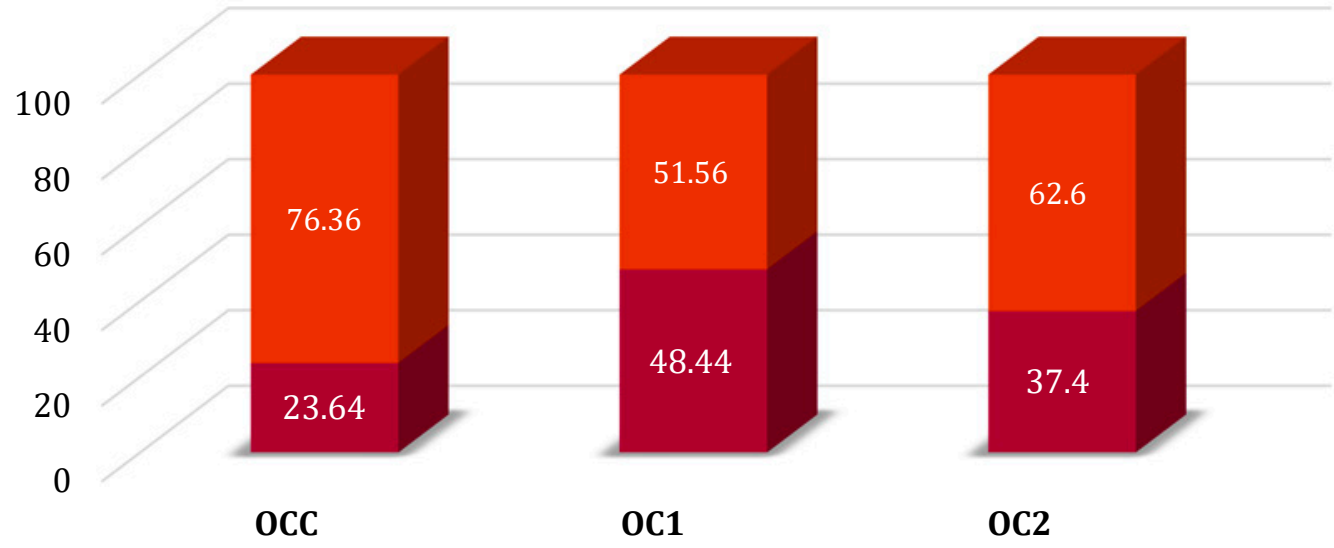

\section{Weight of root (\%) $\quad$ Weight of above-ground parts (\%)}

Figure 9 Comparison of the ratio of the weight of root (\%) and the weight of above-ground plant biomass (\%) of the total weight of the above-ground mass in the control variant and after application of ALGEX 6 in both variants: OCC - control; OC1 - variant 1; OC2 - variant 2

80.00

70.00

60.00

50.00

40.00

30.00

20.00

10.00

0.00

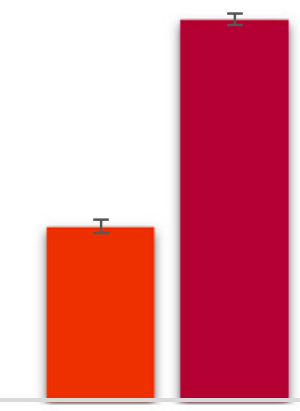

OCC DL

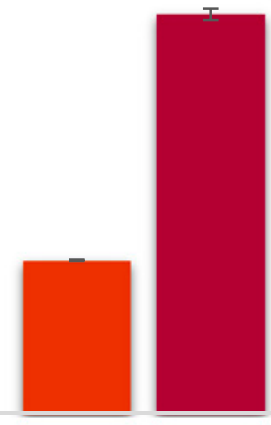

OCC DH

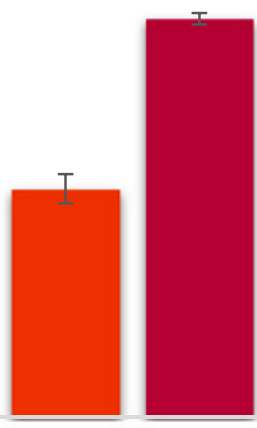

OC1 DL

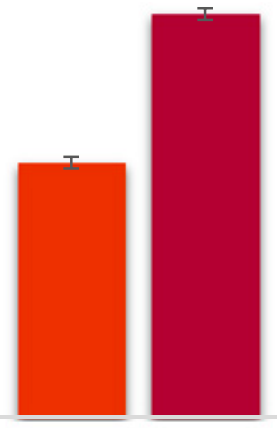

OC1 DH

Figure 10 Comparison of antioxidant activity (\%) in dried leaves (DL) and whole plants (DH) in aqueous and methanol extracts of Ocimum $\times$ citriodorum Vis. grown in control variant (OCC) and after applications of ALGEX $_{r} 6$ in variants OC1 and OC2

Table 9 Analysis of variance to evaluate the antioxidant activity in aqueous and methanol extracts of Ocimum $\times$ citriodorum Vis.) grown in control variant (OCC) and after applications of ALGEX $_{\mathrm{r}} 6$ in variants OC1 and OC2

\begin{tabular}{|l||c|c|c|c|c|}
\hline Effect & SS & df & MS & F & p-value \\
\hline \hline \multicolumn{7}{|c|}{ AA - Aqueous Extract } \\
\hline Absolute Member & 14811.51 & 1 & 14811.51 & 2253.82 & 0.00 \\
\hline Variant & 599.79 & 3 & 199.93 & 30.422 & 0.00 \\
\hline Statistical Error & 52.57 & 8 & 6.57 & & \\
\hline \multicolumn{7}{|c|}{ AA - Methanol Extracts } \\
\hline Absolute Member & 56435.06 & 1 & 56435.06 & 13218.96 & 0.00 \\
\hline Variant & 26.15 & 3 & 8.72 & 2.04 & 0.19 \\
\hline Statistical Error & 34.15 & 8 & 4.27 & & \\
\hline
\end{tabular}

Note: AA - antioxidant activity; SS - sum of squares; df - degrees of freedom; MS - mean square; F - F statistic; p-value - probability ( $\alpha=0.05)$ 
Table 10 Statistical differences in antioxidant activity between dried leaves (DL) and dried whole plants (DH) of Ocimum $\times$ citriodorum (OC) determined in aqueous (AE) and methyl alcohol extracts (ME) by Fischer test (LSD).

\begin{tabular}{|c|c|c|c|c|c|c|c|c|c|c|}
\hline Variants & $x$ & $\partial^{\circ}$ & 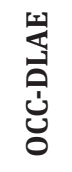 & 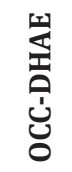 & 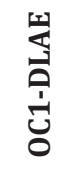 & 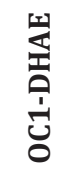 & $\begin{array}{l}\sum_{j}^{1} \\
0 \\
\text { ப̇ } \\
0\end{array}$ & 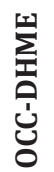 & 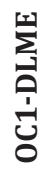 & 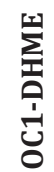 \\
\hline OCC-dried leaves aqueous extract & 30.16 & 6.66 & & & & & & & & \\
\hline OCC-dried herbs aqueous extract & 26.55 & 0.83 & - & & & & & & & \\
\hline OC1-dried leaves aqueous extract & 39.65 & 11.02 & + & + & & & & & & \\
\hline oc1-dried herbs aqueous extract & 44.14 & 3.96 & +++ & +++ & + & & & & & \\
\hline OCC-dried leaves methanol extract & 66.08 & 4.94 & +++ & +++ & +++ & +++ & & & & \\
\hline OCC-dried herbs methanol extract & 69.18 & 1.14 & +++ & +++ & +++ & +++ & - & & & \\
\hline oC1-dried leaves methanol extract & 69.11 & 1.82 & +++ & +++ & +++ & +++ & - & - & & \\
\hline oc1-dried herbs methanol extract & 69.92 & 2.92 & +++ & +++ & +++ & +++ & - & - & - & \\
\hline
\end{tabular}

Note: - - differences are disproven; + - differences are statistically significant; +++ - statistical significance with even smaller differences; arithmetic mean; V \% - coefficient of variation (\%)

and at the same time significant effect of alginite (crushed from) and its extracts was manifested especially in increasing of germination by $340.00 \%$ (alginite extract), increasing average germination by $201.70 \%$ (crushed alginate) and by $334.20 \%$ (alginite extract), values of the mean germination time showed a shortening with using by 4.95 days (alginite extract), by 3 days (crushed alginite), by 2.82 days (powder application) compared to the controls.

\section{Conclusions}

Alginite as a bituminous rock is specific to the components of some types of kerogen with predominating kerogen type II. In addition to organic matter, the rock contains a spectrum of micronutrients - macroelements, mainly $\mathrm{P}, \mathrm{K}, \mathrm{Ca}$ and $\mathrm{Mg}$, as well as a large number of microelements. Many plant species responded to the application of alginite with various effects during germination, growth, development, production of seeds, fruits, but also by increasing many biologically active substances, which also contribute to the quality of plant parts. We did not evaluate the content of their specific biologically active substances in the tested medicinal plant species. Reducing the weight of roots and above-ground parts of plants generally has a positive effect on the increase of biologically active substances in medicinal plant species. This trend was reflected by increasing antioxidant activity in the evaluated species.

\section{Acknowledgments}

The scientific work was processed within the solution of contract research of the organic mineral alginite with the financial support and consent of GEOCOMPLEX, a. s. company. The results of this research are the asset of GEOCOMPLEX, a. s. company. This study was supported by Visegrad Scholarship Fund (\#52010762) and SAIA for the scholarship grants for the research stay during which the presented knowledge was obtained.

\section{References}

ADZET, T., PONZ, R., WOLF, E., SCHULTE, E. 1992. Content and composition of $M$. officinalis oil in relation to leaf position and harvest time. In Planta Med., vol. 58, p. 562.

BALAEVA-TICHOMIROVA, O., LEONOVICH, E. 2017. Assesment of antioxidant properties of early-flowering plants. In Agrobiodiversity for Improving Nutrition, Health and Life Quality, vol. 1, p. 21-25. http://dx.doi. org/10.15414/agrobiodiversity.2017.2585-8246.21-25

BAO, L., BAO, X., LI, P, WANG, X., AO, W. 2018. Chemical profiling of Malva verticillata L. by UPLC-Q-TOF-MSE and their antioxidant activity in vitro. In Journal of Pharmaceutical and Biomedical Analysis, vol. 150, p. 420-426. https://doi.org/10.1016/j.jpba.2017.12.044

BELÁČEK, B. 2006. Možnosti využitia novej suroviny alginitu $v$ lesnom hospodárstve [Possibility of using new material - alginate in forestry]. PhD Thesis, Zvolen : Technical University of Zvolen, p. 108. [In Slovak].

BRAND-WILLIAMS, W., CUVELIER, M. E., BERSET, C. 1995. Use of a free radical method to evaluate antioxidant activities. In Lebensmittel Wissenschaft und Technologie, vol. 28(1), p. 25-30. https://doi.org/10.1016/S0023-6438(95)80008-5

DLAPA, P., DOERR, S.H., LICHNER, L', ŠIR, M., TESAŘ, M. 2004. Effect of kaolinite and Ca-montmorillonite on the alleviation of soil water repellency. In Plant, Soil and Environment, vol. 8, p. 358-363. 
FERNANDEZ, M.T.H., MATAIX-SOLERA, J., LICHNER, L'., ŠTEKAUROVA, V., ZAUJEC, A., IZQUIERDO, C. G. 2007. Assessing the microbiological, biochemical, soilphysical and hydrological effects of amelioration of degraded soils in semiarid Spain. In Biologia, vol. 62, p. 542-546.

GREGOR, J., BUBLINEC, E. 1999. Využitie alginitu pre regeneráciu a stabilitu pôd [Use of alginite for soil regeneration and stability]. In Acta facultatis forestalis Zvolen Slovakia, Zvolen: Technická univerzita vo Zvolene, vol. 41, p. 43-54. ISBN 80-228-0872-5. [In Slovak]

HAKKIM, F.L., ARIVAZHAGAN, G., BOOPATHY, R. 2008. Antioxidant property of selected Ocimum species and their secondary metabolite content. In Journal of Medicinal Plants Research, vol. 2(9), p. 250-257.

ISMAIL, S.M., OZAWA, K. 2007. Improvement of crop yield, soil moisture distribution and water use efficiency in sandy soils by clay application. In Applied Clay Science, vol. 37, p. 81-89.

IVANIŠOVÁ, E., MITTUCHOVÁ, K., MAREČEK, J., FRANČÁKOVÁ, H. 2017. Small berries - attractive source of bioactive compounds for consumers. In Agrobiodiversity for Improving Nutrition, Health and Life Quality, vol. 1, p. 168-173. http://dx.doi.org/10.15414/ agrobiodiversity.2017.2585-8246.168-17

IVANIŠOVÁ, E., VASKOVÁ, D., ZAGULA, G., GRYNSHPAN, D., SAVITSKAYA, T. A., KAČÁNIOVÁ, M. 2020. Phytochemical profile and biological activity o elected kind of medicinal herbs. In Potravinarstvo Slovak Journal of Food Sciences, vol. 14, p. 573-579. https://doi.org/10.5219/1370

JAMBOR, A., SOLTI, G. 1975. Geological conditions of the Upper Pannonian oil shale deposit recovered in the Balaton Highland and at Kemenyeshat. In Acta Mineralogica et Petrographica, vol. 22, p. 9-28.

JULIANI, H. R., SIMON, J. E. 2002. Antioxidant activity of basil. In Trends in new crop and new uses. In: JANICK, J. AND WHIPKEY, A. (eds.). ASHS Press, Alxandria, VA.

KOVÁR, P., VOZÁR, L., HRIC, P., BRINDZA, J., VEREŠOVÁ, P. 2021. Vplav alginitu a extraktov z neho na klíčenie lipnice lúčnej (Poa pratensis L.) (Influence of Alginite and Extracts from it on Germination of Kentucky bluegrass (Poa pratensis L.). In Proceedings: XV. národní odborný a vedecký seminár "Osivo a sadba", February $4^{\text {th }}$, p. 137-142. ISBN 978-80-213-3080-1. [In Slovak].

KULICH, J., VALKO, J., OBERNAUER, D. 2001. Perspective of exploitation of alginite in plant nutrition. In Journal of Central European Agriculture, vol. 2, p. 199-206.

LOIZZO, M. R., PUGLIESE, A., BONESI, M., TENUTA, M. C., MENICHINI, F., XIAO, J., TUNDIS, R. 2016. Edible flowers a rich source of phytochemicals with antioxidant and hypoglycemic properties. In J. Agric. Food Chem., vol. 64(12), p. 2467-2474. https://doi.org/10.1021/acs.jafc.5b03092

MAJDI, CH. et al. 2020. Phytochemical Characterization and bioactive properties of cinnamon basil (Ocimum basilicum cv. 'Cinnamon') and lemon basil (Ocimum $\times$ citriodorum). In Antioxidants (Basel), MDPI, 369 p. https://doi.org/10.3390/antiox9050369
MARTINS, N.E.N., PESSANO, T.C., LEAL, L. 2012. Protective effect of Melissa officinalis aqueous extract against Mninduced oxidative stress in chronically exposed mice. In Brain Research Bulletin, vol. 87(1), p. 74-79.

MIKHAILOVA, S.I., EBEL, A.L. 2015. Malva verticillata L. and Vicia hirsuta (L.) S.F. Gray - invasive species of Siberia (Overview). In Biosciences Biotechnology Research Asia, vol. 12(3), p. 2045-2052. http://dx.doi.org/10.13005/bbra/1872

MIRAJ, S., AZIZI, N., KIANI, S. 2016. A review of chemical components and pharmacological effects of Melissa officinalis L. In Der Pharmacia Lettre, vol. 8, no. 6, p. 229-237.

MŇAHONČAKOVÁ, E., VERGUN, O., SVYDENKO, L., HORČINOVÁ SEDLAČKOVÁ, V., HRÚZOVÁ, M., BRINDZA, J., IVANIŠOVA, E. 2019. Antioxidant potential of Lamiaceae herbs from Botanical Garden of Slovak University of Agriculture in Nitra. In Agrobiodiversity for Improving Nutrition, Health and Life Quality, vol. 3, p. 462-472. https://doi.org/10.15414/ agrobiodiversity.2019.2585-8246.462-47

MOACA, E-A., FARCAS, C., GHITU, A., CORICOVAC, D., POPOVICI, R., CARABA-MEITA, N-L., DEHELEAN, C., AVRAM, S. 2018. A comparative study of Melissa officinalis leaves and stems ethanolic extracts in terms of antioxidant, cytotoxic and antiproliferative potential. In Hindawi Evidence-Based Complementary and Alternative Medicine, vol. 2018, Article ID 7860456. https://doi.org/10.1155/2018/7860456

MOTYLEVA, S., BRINDZA, J., OSTROVSKY, R., MERTVICHEVA, M. 2014. Physical and chemical characteristics of Pincina alginate. In Advances in Materials Science Research (Numered series), Material Science, Technology and Engineering, vol. 17, Maryann C. Wythers (ed.): NOVA, 231 p. ISBN 978-1-62948-734-2.

OGNJANOVA-RUMENOVA, N., VASS, D. 1998. Palaeoecology of the late miocene maar lakes, Podrecany basalt formation, Southern Slovakia, on the basis of siliceous microfossils. In Geologica Carpathica, vol. 49 (5), p. 351-368.

PAPOTI, V. T., TOTOMIS, N., ATMATZIDOU, A., ZINOVIADOU, K., ANDROULAKI, A., PETRIDIS, D., RITZOULIS, C. 2019. Phytochemical content of Melissa officinalis L. herbal preparations appropriate for consumption. In Processes, vol. 7(2), 88, p. 1-16. https://doi.org/10.3390/pr7020088

PHIPPEN, W. B., SIMON, J. E. 1998. Anthocyanins in basil (Ocimum basilicum L.). In Journal of Agricultural and Food Chemistry, vol. 46, p. 1734-1738.

PHIPPEN, W. B., SIMON, J. E. 2000. Anthocyanin inheritance and instability in purple basil (Ocimum basilicum L.). In Journal of Heredity, vol. 91, p. 289-296.

PRUGAR, J. 2008. Kvalita rostlinných produktů na prahu 3. tisíciletí [The quality of plant products on the threshold of the $3^{\text {rd }}$ millennium]. Praha: Výzkumný ústav pivovarský a sladařský ve spolupráci s komisí jakosti rostlinných produktů ČAZV. ISBN 978-80-8657628-2. [In Czech] 
RASMUSSEN, P. 2011. Lemon balm: Melissa officinalis; also known as lemon balm, bee balm, garden balm, Melissa, melissengeist, In Journal of Primary Health Care, vol. 3(2), p. 165-166.

RIBEIRO, M. A., BERNOARDO-GIL, M.G., ESQUIVEL, M.M. 2001. Melissa officinalis L.: study of antioxidant activity in supercritical residues. In Journal of Supercritical Fluids, vol. 21, p. 51-60.

RICE-EVANS, C.A., MILLER, N.J., PAGANGA, G. 1996. Structureantioxidant activity relationships of flavonoids and phenolic acids. In Free Radical Biology and Medicine, vol. 20, p. 933-956.

RICE-EVANS, C.A., MILlER, N.J., PAGANGA, G. 1997. Antioxidant properties of phenolic compounds. In Trends in Plant Science, vol. 2, p. 152-159.

RUSSELL, P. L. 1990. Oil Shales in the World, Their Origin, Occurences and Exploitation. Pergamon Press : New York, p. 412-450.

SCALBERT, A., WILLIAMSON, G. 2000. Dietary intake and bioavailability of polyphenols. In Journal of Nutrition, vol. 130, p. 2073S-2085S.

SCHACHTSCHABEL, P., BLUME, H.P., HARTGE, K.H., SCHWERTMANN, U. 1984. Lehrbuch der Bodenkunde. Stuttgart. Ferdinand Enke Verlag : Germany, 442 p.

SHANAYDA, M.I., KORABLOVA, O.A. 2015. The results of introduction and phytochemical research of Ocimum americanum L. under condition of Western Podillja of Ukraine. In Agrobiodiversity for Improving Nutrition, Health and Life Quality, p. 593-596.

SHYMANSKA, O., VERGUN, O., FISHCHENKO, V., RAKHMETOV, D. 2020. Antioxidant potential of some Asteraceae Bercht. \& J. Presl. representatives. In Agrobiodiversity for Improving Nutrition, Health and Life Quality, vol. 4, p. 70-77. https://doi.org/10.15414/ agrobiodiversity.2020.2585-8246.070-77

SHYMANSKA, O., VERGUN, O., RAKHMETOV, D., BRINDZA, J., IVANIŠOVÁ, E. 2018. A total content of phenolic compounds in the ethanol extracts of Galega officinalis L. and $G$. orientalis Lam. In Agrobiodiversity for Improving Nutrition, Health and Life Quality, vol. 2, p. 140-145. https://doi.org/10.15414/agrobiodiversit у.2018.2585-8246.140-145

SKYBITSKA, M., LYSHAK, M., IEVTUKH, V. 2015. Biological features Salvia officinalis L. in the Botanic Garden of Lviv National Ivan Franko University. In Scientific Proceedings of the International network AgroBioNet: Agrobiodiversity for Improving Nutrition, Health and Life Quality, p. 616-618.

SOLTI, G. 1987. Az Alginit [The alginite]. Budapest : A Magyar Állami Földtani Intézet Alkalmi Kiadványa, 40 p. [In Hungarian]

STEHLÍKOVÁ, B. 1998. Základy bioštatistiky [Fundamentals of biostatistics]. Učebné texty pre dištančné štúdium. Nitra: Ochrana biodiverzity. [In Slovak]
SVIDENKO, L.V., BRINDZA, J., BROVARSKIY, V.D., SVIDENKO, A.V. 2015a. The use of aromatic and medicinal plants and honey. In Scientific Proceedings of the International network AgroBioNet: Agrobiodiversity for Improving Nutrition, Health and Life Quality, p. 644-648.

SVIDENKO, L.V., VERGUN, E.N., BRINDZA, J., SVIDENKO, S.V. 2015b. Determination of antioxidant activity of some plants of familiy Lamiaceae Martinov. In Scientific Proceedings of the International network AgroBioNet: Agrobiodiversity for Improving Nutrition, Health and Life Quality, p. 649-652.

VASS, D., BUBLINEC, E., HALAS, L., BELAČEK, B. 2003. Overview of Pincina alginite fertility. In Földtani Kutatas, vol. 15, p. 75-80.

VASS, D., ELEČKO, M., KONEČNY, V. 1997. Alginite, a raw material for environmental control. In Geology Today, vol. 13, p. 149-153.

VERGUN, O., BRINDZA, J., RAKHMETOV, D. 2017. Total antioxidant Activity of plants of Symphytum L. species. In Agrobiodiversity for Improving Nutrition, Health and Life Quality, vol. 1, p. 488-492. http://dx.doi.org/10.15414/ agrobiodiversity.2017.2585-8246.488-49

VERGUN, O., KAČÁNIOVÁ, M., RAKHMETOV, D., SHYMANSKA, O., BONDARCHUK, O., BRINDZA, J., IVANIŠOVÁ, E. 2018. Antioxidant and antimicrobial activity of Bunias orientalis L. and Scorzonera hispanica L. ethanol axtracts. In Agrobiodiversity for Improving Nutrition, Health and Life Quality, vol. 2, p. 29-38. https://doi.org/10.15414/ agrobiodiversity.2018.2585-8246.029-03

VERGUN, O., SVYDENKO, L., GRYGORIEVA, O., SHYMANSKA, O., RAKHMETOV, D., BRINDZA, J., IVANIŠOVÁ, E. 2019. Antioxidant capacity of plant raw material of Scutellaria baicalensis Georgi. In Potravinarstvo Slovak Journal of Food Sciences, vol. 13(1), p. 614-621. https://doi.org/10.5219/1090

VERGUN, O.M., RAKHMETOV, D., SHYMANSKA, O., BONDARCHUK, O.P., IVANIŠOVÁ, E., KAČÁNIOVÁ, M., GRYGORIEVA, O.V., BRINDZA, J. 2021. Assessment of antioxidant and antimicrobial activities of Crambe spp. during vegetation. In Acta Sci Pol Technol Aliment, vol. 20(2), p. 197-211. http://dx.doi.org/10.17306/J.AFS.2021.0927

VON GADOW, A., JOUBERT, E., HANSMANN, C. F. 1997. Comparison of the antioxidant activity of rooibos tea (Aspalathus linearis) with green, oolong and black tea. In Food Chemistry, vol. 60(1), p. 73-77. https://doi.org/10.1016/S0308-8146(96)00312-3 